\title{
VIRTUAL POPULATION ANALYSIS OF TWO SNAPPER SPECIES, LUTJANUS ANALIS AND LUTJANUS CHRYSURUS, CAUGHT OFF PERNAMBUCO STATE, NORTH-EASTERN BRAZIL
}

\author{
Sérgio Macedo Gomes de Mattos ${ }^{1}$ and Francesc Maynou ${ }^{2}$
}

${ }^{1}$ Secretaria Especial de Aquicultura e Pesca (SEAP), Escritório no Estado de Pernambuco (Av. Gal. San Martin, 1000, 50630-060 Bongi, Recife, PE, Brasil)

E-mail: sergiomattos@seap.gov.br

${ }^{2}$ Institut de Ciències del Mar (ICM-CSIC)

(Psg. Marítim de la Barceloneta 37-49, 08003 Barcelona, Spain)

E-mail: maynouf@icm.csic.es

\section{A B S T R A C T}

We applied steady-state Virtual Population Analysis - VPA to two stocks of snappers (Lutjanus analis and L. chrysurus) exploited by artisanal hand-line fleets along the Pernambuco State coast (North-eastern Brazil). We show that even short-data series (1 year of sampling) can produce a useful diagnosis of fisheries resources. Both stocks are slightly overexploited by the hand-line fishery and a higher yield-per-recruit would be obtained by a reduction of effort of $16 \%$ for L. analis and $43 \%$ for L. chrysurus. Given the impracticability of managing the two stocks separately, we propose a $25 \%$ decrease of fishing effort for the hand-line fleet. By incorporating the results of VPA into a simulation framework, we can develop a comparison of the likely result of different policy options (effort regulation) based on 3 simple indicators (Spawning stock biomass-per-recruit, biomass-perrecruit and yield-per-recruit). We compare the results of effort reduction with those of effort increase $(25 \%)$ through simulation analysis. Allowing for the difficulty of testing assumptions introduced in our model (steady-state, Beverton and Holt recruitment model) and using standard fisheries analysis techniques, we show that useful fisheries advice can be produced even in a context of limited data. Providing advice to developing countries coastal fisheries is an urgent issue, given the high dependence of local communities on coastal living resources and the increasing fishing effort applied by a growing population.

\section{RESUMO}

Foi aplicado a Análise Virtual de População - VPA em estado estacionário a dois estoques de lutjanídeos (Lutjanus analis e L. chrysurus) explorados pela frota artesanal de linha de mão ao longo da costa do Estado de Pernambuco (Nordeste do Brasil). Demonstrou-se que mesmo para uma série de dados não-históricos (1 ano de amostragem) pode-se produzir um diagnóstico útil dos recursos pesqueiros e que ambos os estoques estão próximo ao estado de sobrexplotação e melhor rendimento por recruta seria obtido com uma redução do esforço de pesca de $16 \%$ para L. analis e de $43 \%$ para L. chrysurus. Dado a impraticabilidade de ordenar os dois estoques separadamente, propõe-se uma diminuição do esforço de pesca em $25 \%$ para a frota de linha de mão. Incorporando os resultados de VPA em estratégias de simulação, pôde-se desenvolver uma comparação dos prováveis resultados das diferentes opções de regulamentação pesqueira (regulamento do esforço) baseadas em 3 simples indicadores (biomassa do estoque reprodutor por recruta, biomassa por recruta e rendimento por recruta). Compararam-se os resultados da redução do esforço com o aumento do esforço (25\%) através de uma análise de simulação. Admitindo as dificuldades em testar as suposições introduzidas em nosso modelo (estado estacionário, modelo de recrutamento de Beverton e Holt) e usando técnicas de análise padrão de pescarias, mostrou-se que medidas adequadas à regulamentação pesqueira podem ser obtidas, mesmo em um contexto de dados limitados. Fornecer recomendações às pescarias costeiras de países em desenvolvimento é uma prioridade, dada a elevada dependência das comunidades pesqueiras locais nos recursos vivos costeiros e do crescente esforço de pesca aplicado por uma população de crescimento.

Descriptors: Virtual population analysis, Coastal fisheries, Snapper, Pernambuco State.

Descritores: Análise virtual da população, Pesca costeira, Lutjanídeos, Pernambuco. 


\section{INTRODUCTION}

The fisheries of Pernambuco State, Northeastern Brazil, are mainly conducted in the coastal zone by artisanal fishermen operating small fishing vessels, producing $13,999.5 \mathrm{t}, 95.3 \%$ of the State's total fish production (IBAMA, 2007). A variety of 16 kinds of fishing gear are used by coastal fishermen, mainly hand-line, gillnets, beach seines and traps. The fishing grounds of the coastal Pernambuco fisheries cover about $1,500 \mathrm{~nm}^{2}$ (Fig. 1), and although official statistics indicate that production seems to be stable, the local fishermen's perception is that the abundance of the coastal fisheries resources is declining and becoming overexploited, due mainly to increasing fishing effort and lack of effective enforcement of fisheries regulations. To provide advice on the optimal effort levels to sustain coastal fisheries in Pernambuco State we applied a relatively simple, but robust, modelling approach to the main species exploited by the hand-line fleet in this area. The approach should enable decision-makers and administrators to obtain a straightforward instrument that can assess possible consequences deriving from the adoption of policy decisions regarding fisheries (WILLMANN; GARCÍA, 1986).

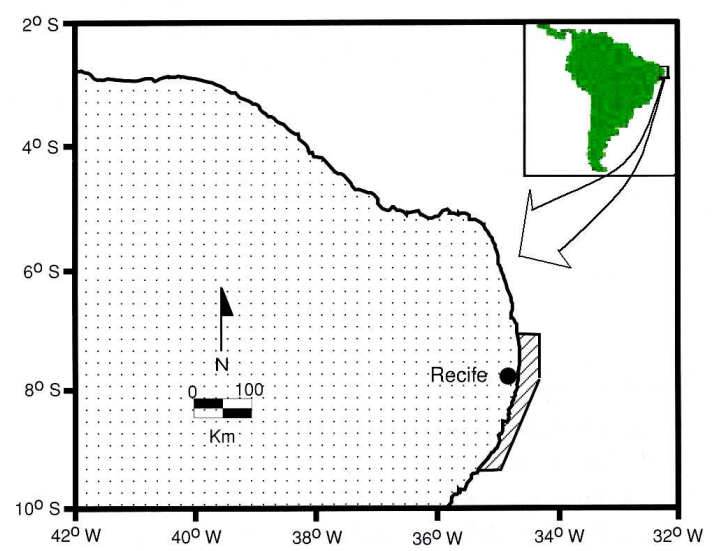

Fig. 1. Operational area of the hand-line artisanal fishing fleet off Pernambuco State, Brazil, continental shelf.

The main fishery resources of the Pernambuco coast are coastal reef fishes, such as snappers (Lutjanidae) and groupers (Serranidae), and although recently biological studies have been conducted, uncertainties regarding the decision as to the right management measure to put into practice is still a concern among scientists and decision makers, because data on these resources are often scarce (MATTOS, 2004; MATTOS et al., 2006). The frequency and distribution of catches of Lutjanid and Serranid species by the artisanal fishing fleet in the Northeast Region of Brazil have been recently reported by Frédou and Ferreira (2005) and Frédou et al. (2006) for Lutjanid and by Teixeira et al. (2004) for Serranid. Both groups are target species for many Brazilian Northeastern Region fleets, especially during periods of feeding aggregation seemingly related to the Southward chain reaction (TEIXEIRA et al., 2004). Nevertheless, to provide a sound basis for fisheries management (PERRINGS, 2000) for the Pernambuco state fishery sector, it is essential to deepen knowledge on the biology of fishing resources, aiming at an adequate comprehension on Lutjanid population dynamics. Leite Jr. et al. (2005) have commented that Lutjanus genus is the most diversified of the Lutjanidae family and the most important from the economic point of view.

The most abundant species in the catches of coastal fisheries (in terms of biomass) is the mutton snapper, Lutjanus analis (CUVIER, 1828), of $160.9 \mathrm{t}$ in 2002, while the most abundant species in number of individuals in the catches is the yellowtail snapper, Lutjanus chrysurus (BLOCH, 1791), of $69.7 \mathrm{t}$ in 2002 (IBAMA, 2003). Frédou and Ferreira (2005) stressed that both mutton snapper and yellowtail snapper, together with the dog snapper, $L$. jocu, inhabit intermediate depths between $20 \mathrm{~m}$ and $80 \mathrm{~m}$, where they are mainly caught. On the other hand, Carvalho Filho (1999) has mentioned that the mutton snapper, a larger lutjanid species, inhabits deeper regions of the continental shelf and the continental slope, whereas younger individuals are more frequently found in shallower regions, and that the yellowtail snapper, a smaller lutjanid species, is more frequent in shallower regions, thus being more vulnerable to the fishing effort applied, due to the accessibility of hand-liners to inshore fishing grounds, and the fishing gear utilised. This aspect is in accordance with the argument of Frédou and Ferreira (2005) for whom a complex of significant factors seems to influence the catch composition and is related to distance from shore and depth of fishing. Although hook-and-line seems to be quite selective, it is known that the size of the hook can lead to great variability in the size of fish caught and may affect selectivity effects.

The objective of this study is to provide a first analysis of the state of two important coastal fishery resources off Pernambuco (Brazil) and provide recommendations on regulating effort levels, although concerned that management strategies based only on the regulation of fishing effort are not effective in protecting snapper species, because lack of governmental control makes it unrealistic to propose management measures based on Total Allowable Catches - TAC, Individual Transferable Quotas ITQ, and even more the use of marine fisheries reserves in the short run, even though we agree that these management strategies must be a priority policy to pursue. We also believe that, although our results 
are based on snapper coastal fisheries, they should contribute to the design of an effective management strategy for Brazil's coastal resources in general.

\section{Material ANd Methods}

\section{Data Source}

The operations of 18 hand-line fishing boats were followed monthly from November 2001 to October 2002. Fishery (catches, effort) and biological information (individual length and weight) were recorded during landings, and through interviews carried out with each fishing boat master and crew. Total and fork length were rounded down to the nearest centimetre and eviscerated weight $(\mathrm{g})$ were recorded for each individual of the 2 species selected for this study (Lutjanus analis and L. chrysurus).

\section{Estimation of Growth Parameters}

Modal progression analysis (Bhattacharya method) was used to establish von Bertalanffy's growth parameters and determine the growth curves (FISAT: GAYANILO et al., 2002). We acknowledge that Modal Progression Analysis - MPA is of limited use in estimating growth parameters for tropical fish species, but it is the only practical method in the absence of costly otolith-based analysis. MPA is also widely used for assessing tropical fisheries (SPARRE et al., 1989). The values of the parameters $L_{\infty}$ and $K$ were validated through Surface Response Analysis and Scanning of K-values (GAYANILO et al., 2002).

$$
\text { Virtual Population Analysis - VPA }
$$

The length-based Virtual Population Analysis (VPA) was performed on the pooled annual length frequencies from the fishery to estimate the mean number in the population and the overall fishing mortality by length group. The overall fishing mortality was sub-divided into fishing mortality by gear-type based on the proportion of individuals caught by each type of gear.

The virtual population of the two snappers, under steady state, was reconstructed using the program "VIT - Software for fishery analysis" (LLEONART; SALAT, 1997). The VIT program, beyond allowing other important indicators of a fish population subject to exploitation to be obtained, also permits a Yield-per-recruit analysis to be made, as well as an analysis of the variations in exploitation rate (simulation analysis) and an assessment of the sensitivity of the results to uncertainty in input parameters. The program works with pseudo-cohorts and is, therefore, suitable for the analysis of non- historical fish catch series, based on the classic catch equation (standard VPA, GULLAND, 1969).

The input value of the terminal fishing mortality $\left(F_{t e r}\right)$ was estimated in the light of the fact that $F$ is proportional to the stock density and the intensity of fishing, defined as the fishing effort per unit of area or, more precisely, related to the stock density and the fishing effort. Due to the uncertainty involved in estimating natural mortality $(M)$, the relationship $Z=F+M$ was used after estimating total $(Z)$ and fishing $(F)$ mortalities, using Beverton and Holt's approach as given in FISAT (GAYANILO et al., 2002).

The impact on the stocks' health (as measured by $\mathrm{SSB} / \mathrm{R}$ and $\mathrm{B} / \mathrm{R}$ ) of varying fishing efforts was analysed within two scenarios of either deterministic or stochastic recruitment, using a plausible set of parameters for Beverton and Holt's stock-recruitment model over a 20-year simulation period. In the stochastic simulation case, the number of iterations performed was 100 . The stochastic model used for recruitment was a lognormal distribution of mean 1 and standard deviation 0.1. The fishing effort variations are given as proportions of current fishing effort (25\% increase, $25 \%$ decrease, or applying effort level which maximizes $\mathrm{Y} / \mathrm{R})$. The results are presented as Yield-per-recruit (Y/R), Biomass-per-recruit (B/R) and Spawning stock biomass-per-recruit (SSB/R).

\section{RESULTS}

A total of 3,749 specimens of $L$. analis were caught during the study and 252 were measured and weighed to determine the length-weight relationships and the frequency distribution for the definition of growth parameters. Length ranged from $32 \mathrm{~cm}$ to 90 cm (TL) (Fig. 2a). A total of 10,152 specimens of $L$. chrysurus were caught and 529 were measured and weighed. Length ranged from $26 \mathrm{~cm}$ to $64 \mathrm{~cm}$ (TL) (Fig. 2b).

\section{Length-at-age and Weight-at-age}

The length-at-age vector computed from von Bertalanffy's growth parameters for L. analis is shown in Table 1. The parameters obtained for the lengthweight relationship were $a=0.0112$ and $b=3.0019$, and for von Bertalanffy's growth curve were $L_{\infty}=$ $108.20 \mathrm{~cm} \mathrm{TL}, W_{\infty}=14.34 \mathrm{~kg}, K=0.168 \mathrm{yr}^{-1}$ and $t_{0}=$ $-0.892 \mathrm{yr}$. The growth equations in length and weight are, therefore:

$$
L_{t}=108.20[1-\exp (-0.168(t+0.892))]
$$

and

$$
W_{e}=14.34[1-\exp (-0.168(t+0.892))]^{3.0019}
$$




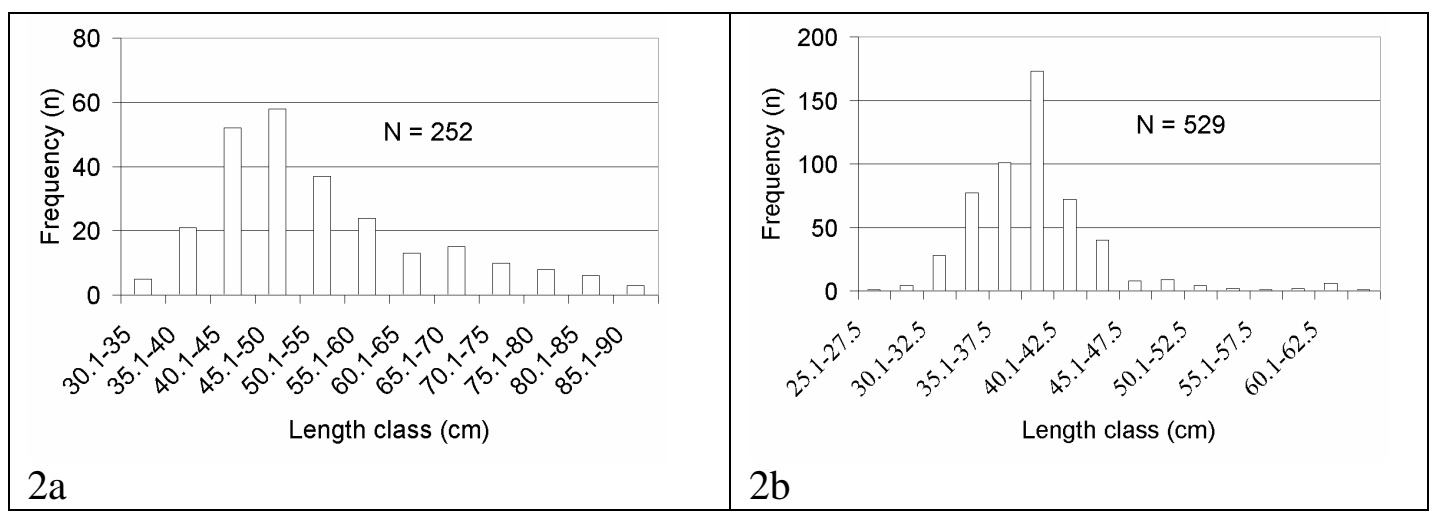

Fig. 2. Length frequency distribution of the mutton snapper, Lutjanus analis (a, left) and the yellowtail snapper, Lutjanus chrysurus (b, right), caught off Pernambuco State, North-eastern Brazil, continental shelf.

Table 1. Age, length and weight vectors for mutton snapper, Lutjanus analis (Cuvier, 1828), caught off Pernambuco State, North-eastern Brazil, continental shelf.

\begin{tabular}{ccc}
\hline \hline Age (year) & $\begin{array}{c}\text { Total } \\
\text { Length - TL } \\
(\mathrm{cm})\end{array}$ & $\begin{array}{c}\text { Eviscerated } \\
\text { Weight - EW } \\
(\mathrm{kg})\end{array}$ \\
\hline 0 & 0 & 0 \\
1 & 16.78 & 0.053 \\
2 & 30.96 & 0.335 \\
3 & 42.94 & 0.895 \\
4 & 53.07 & 1.690 \\
5 & 61.62 & 2.646 \\
6 & 68.84 & 3.692 \\
7 & 74.95 & 4.764 \\
8 & 80.11 & 5.818 \\
9 & 84.47 & 6.820 \\
10 & 88.15 & 7.752 \\
11 & 91.26 & 8.603 \\
12 & 93.89 & 9.370 \\
13 & 96.11 & 10.050 \\
14 & 97.98 & 10.650 \\
15 & 99.57 & 11.176 \\
\hline & & \\
\hline
\end{tabular}

The length-at-age vector computed from the von Bertalanffy's growth parameters for $L$. chrysurus is shown in Table 2. The parameters obtained for the length-weight relationship were $a=0.0183$, and $b=$ 2.7753; and for von Bertalanffy's growth curve $\mathrm{L}_{\infty}=$ $76.67 \mathrm{~cm} \mathrm{TL} ; W_{\infty}=3.104 \mathrm{~kg} ; K=0.158 \mathrm{yr}^{-1}$; and $t_{0}=$ $0.728 \mathrm{yr}$. The growth equations in length and weight are, therefore:

$$
L_{t}=76.67[1-\exp -(0.158(t+0.728))]
$$

and

$W_{e}=3.104[1-\exp (-0.158(t+0.728))]^{2.7753}$

Table 2. Age, length and weight vectors for yellowtail snapper, Lutjanus chrysurus (Bloch, 1791), caught off Pernambuco State, North-eastern Brazil, continental shelf.

\begin{tabular}{ccc}
\hline \hline Age (year) & $\begin{array}{c}\text { Total } \\
\text { Length }- \text { TL } \\
(\mathrm{cm})\end{array}$ & $\begin{array}{c}\text { Eviscerated } \\
\text { Weight }- \text { EW } \\
(\mathrm{kg})\end{array}$ \\
\hline 0 & 0 & 0 \\
1 & 11.21 & 0.015 \\
2 & 20.77 & 0.083 \\
3 & 28.94 & 0.208 \\
4 & 35.92 & 0.378 \\
5 & 41.87 & 0.579 \\
6 & 46.96 & 0.796 \\
7 & 51.30 & 1.018 \\
8 & 55.01 & 1.235 \\
9 & 58.17 & 1.443 \\
10 & 60.87 & 1.637 \\
11 & 63.18 & 1.815 \\
12 & 65.15 & 1.976 \\
13 & 66.84 & 2.121 \\
14 & 68.27 & 2.250 \\
15 & 69.50 & 2.364 \\
\hline
\end{tabular}

Virtual Population Analysis

Fishing mortality $(F)$ for $L$. analis was estimated on the basis of CPUE and the catchability coefficient $(q)$. Considering a CPUE of $22.48 \mathrm{~kg} / 100$ hooks, a total annual catch of $160.9 \mathrm{t}$ (IBAMA, 2003), a total effort $(f)$ of 28,316 hooks, and a coefficient of catchability of $0.97 \times 10^{-5}$ hook $^{-1} \cdot$ year $^{-1}, F$ was 
calculated to be $0.277 \mathrm{yr}^{-1}$. The total mortality $(Z)$ was estimated as 0.429 , yielding an estimate of natural mortality $(M)$ equal to 0.152 . With the same approach for $L$. chrysurus and using CPUE $=17.62 \mathrm{~kg} / 100$ hooks, a total annual catch of 97.6 $\mathrm{t}$ (IBAMA, 2003), and a coefficient of catchability $(q)$ of $1.26 \times 10^{-5}$ hook $^{-1}$. year ${ }^{-1}, F$ was calculated to be $0.358 \mathrm{yr}^{-1}$. The total mortality $(Z)$ was estimated at 0.470 , yielding an estimate of $M$ equal to 0.112 .

It was not possible to estimate the maturity from the sampling and the average-length-at-maturity was taken from Froese and Pauly (2003). According to these authors, $L$. analis first mature between $40 \mathrm{~cm}$ and $50 \mathrm{~cm}$. It was considered, thus, that the onset of maturity occurs in length classes $40-45 \mathrm{~cm}$, while all individuals above $45 \mathrm{~cm}$ were assumed to be mature. With the population reconstructed by age, instead of length, we estimated that $7 \%$ of the population reached maturity during the first year of life, while $83.6 \%$ of the individuals belonging to the age-class 2 were mature as were also all individuals in the $3+$ yearclass. Age-class 2 showed the highest mortality rates, estimated at $Z=0.654 \bullet \mathrm{yr}^{-1}$ and corresponding to $F=$ $0.502 \cdot \mathrm{yr}^{-1}$. The summary results of the steady state VPA are shown in Table 3.

The current mean age of the stock of $L$. analis is $2.9 \mathrm{yr}$, although effort is being applied mainly to individuals slightly older ( $3.2 \mathrm{yr})$ than the critical age $(3 \mathrm{yr})$, which means that the spawning stock's population status is not heavily fished. On the other hand, the virgin stock's critical age $(8 \mathrm{yr})$ is much higher than the mean age of the catch, and the number of recruits $(38,542)$ is relatively low, suggesting that the exploitation pattern should be improved. The balance between biomass and catch $(33.7 \%)$ and the fishing mortality $(F)$ rates (mean $0.313 \mathrm{yr}^{-1}$; global 0.3 $\left.\mathrm{yr}^{-1}\right)$ showed that the rate of exploitation $(F / Z)$, or the rate of current catch per unit of production $(D)$, is $68.89 \%$, while the natural mortality represents $31.11 \%$ of the biomass balance. Also, the production per unit of biomass, expressed as turnover $\left(D / B_{\text {mean }}\right)$ and as a percentage, shows a rate of $48.9 \%$, which is equivalent to the total mortality rate in terms of biomass.

For $L$. chrysurus, the length at first maturity is reported as $25-30 \mathrm{~cm}$ TL (FROESE; PAULY, 2003). It was considered that the onset of maturity occurs at length classes $27.6-30 \mathrm{~cm}$ TL, and that those individuals above $30 \mathrm{~cm}$ were assumed to be mature. With the population reconstructed by age, we estimated that $73.8 \%$ of the individuals belonging to age-class 2 were mature, while all those in the ageclass 3+ were mature. Age-class 4 showed the higher mortality rate, with $Z=1.296 \mathrm{yr}^{-1}$ and $F=1.184 \mathrm{yr}^{-1}$. The summary results of the steady state VPA are shown in Table 4.
Table 3. Summary information of the virtual population analysis (VPA) for mutton snapper, Lutjanus analis, caught off Pernambuco State, North-eastern Brazil, continental shelf.

\begin{tabular}{|c|c|}
\hline $\begin{array}{l}\text { VPA Parameters } \\
\text { Catch Data }\end{array}$ & Results \\
\hline Catch mean age (year) & 3.169 \\
\hline Catch mean length $(\mathrm{cm})$ & 51.708 \\
\hline Mean Fishing Mortality, $F$ & 0.313 \\
\hline Global Fishing Mortality, $F$ & 0.3 \\
\hline Total catch / year $(\mathrm{g})$ & 47047366.2 \\
\hline Catch / Biomass Balance, $D(\%)$ & 68.89 \\
\hline Catch/Biomass, $B(\%)$ & 33.66 \\
\hline \multicolumn{2}{|l|}{ Population Status } \\
\hline Current Stock Mean Age (year) & 2.879 \\
\hline Current Stock Critical Age (year) & 3 \\
\hline Virgin Stock Critical Age (year) & 8 \\
\hline Current Stock Mean Length $(\mathrm{cm})$ & 48.54 \\
\hline Current Stock Critical Length (cm) & 51.913 \\
\hline Virgin Stock Critical Length (cm) & 83.9 \\
\hline Number of recruits, $R$ & 38541.86 \\
\hline Mean Biomass, Bmean (g) & 139779837 \\
\hline Spawning Stock Biomass (SSB) (g) & 119641040 \\
\hline Biomass Balance $(D)(\mathrm{g})$ & 68293901.5 \\
\hline Natural death / $D(\%)$ & 31.11 \\
\hline $\begin{array}{l}\text { Maximum Biomass, Bmax / Mean } \\
\text { Biomass, Bmean }\end{array}$ & 17.13 \\
\hline Turnover, D/Bmean $(\%)$ & 48.86 \\
\hline \multicolumn{2}{|l|}{ Recruitment } \\
\hline Biomass/Recruit (B/R) & 3626.702 \\
\hline $\begin{array}{l}\text { Stock Spawning Biomass/Recruit } \\
\text { (SSB/R) }\end{array}$ & 3104.184 \\
\hline Yield/Recruit (Y/R) & 1220.682 \\
\hline
\end{tabular}

The current mean age of this stock is $2.6 \mathrm{yr}$, although fishing effort is mainly applied to individuals older (3.6 yr) than the critical age ( $3 \mathrm{yr})$, suggesting that this stock is not heavily fished either. However, the virgin stock's critical age (9 yr) is much higher than the mean catch-at-age and the low number of recruits $(78,478)$ suggests that the exploitation pattern should likewise be improved. The balance between biomass and catch $(49.8 \%)$ and the fishing mortality rates (mean $0.428 \mathrm{yr}-1$; global $0.306 \mathrm{yr}-1$ ) showed that the rate of current catch per unit of production $(D)$ is $81.64 \%$, while natural mortality represents only $18.36 \%$ of the biomass balance. Also, the production per unit of biomass, expressed as turnover $\left(D / B_{\text {mean }}\right)$ and as a percentage, shows a rate as high as $61 \%$, which is equivalent to the total mortality rate in terms of biomass. 
Table 4. Summary information of the virtual population analysis (VPA) for yellowtail snapper, Lutjanus chrysurus, caught off Pernambuco State, North-eastern Brazil, continental shelf.

\section{VPA Parameters
Catch Data \\ Catch mean age (year)}

Catch mean length $(\mathrm{cm})$

Mean Fishing Mortality, $F$

Global Fishing Mortality, $F$

Total catch / year $(\mathrm{g})$

Catch / Biomass Balance, D (\%)

Catch/Biomass, $B(\%)$

Population Status

Current Stock Mean Age (year)

Current Stock Critical Age (year)

Virgin Stock Critical Age (year)

Current Stock Mean Length (cm)

Current Stock Critical Length (cm)

Virgin Stock Critical Length (cm)

Number of recruits, $R$

Mean Biomass, Bmean (g)

Spawning Stock Biomass (SSB) (g)

Biomass Balance $(D)(\mathrm{g})$

Natural death / $D(\%)$

Maximum Biomass, Bmax / Mean

Biomass, Bmean

Turnover, D/Bmean (\%)

\section{Recruitment}

Biomass/Recruit (B/R)

Stock Spawning Biomass/Recruit (SSB/R)

Yield/Recruit (Y/R)

\section{Yield-per-recruit}

The results of the yield-per-recruit analyses are shown in Table 5 and Figure 3 for L. analis, and Table 6 and Figure 4 for $L$. chrysurus. At current levels of fishing effort $(f=1)$ both stocks are slightly overexploited and the yield would improve by reducing fishing effort (Figs 3 and 4, left panels). Levels of both biomass-per-recruit and spawning stock biomass-per-recruit are at low levels under the current exploitation regime and could be improved by substantially reducing fishing effort (Figs. 3 and 4 , right panels). The maximum yield per recruit for the stock of $L$. analis would be obtained by decreasing $f$ to 0.84 (reduction of $16 \%$ ), while a reduction of $f$ to 0.57 (reduction of $43 \%$ ) would ensure the maximum yield per recruit for L. chrysurus.

Table 5. Results of the yield-per-recruit analysis for the mutton snapper, Lutjanus analis, caught off Pernambuco State, North-eastern Brazil, continental shelf.

\begin{tabular}{llll}
\hline \hline Slope at origin & 4889.9067 & & \\
\hline Virgin biomass & 602964715 & & \\
\hline Factor & $\mathrm{Y} / \mathrm{R}$ & $\mathrm{B} / \mathrm{R}$ & $\mathrm{SSB} / \mathrm{R}$ \\
0 & 0 & 15644.411 & 15041.281 \\
0.58 & 1185.883 & 6216.591 & 5663.17 \\
0.84 & 1234.265 & 4451.66 & 3917.09 \\
1.01 & 1220.682 & 3626.702 & 3104.184 \\
2 & 998.56 & 1495.692 & 1033.745 \\
\hline
\end{tabular}

677.036

524.976

337.183

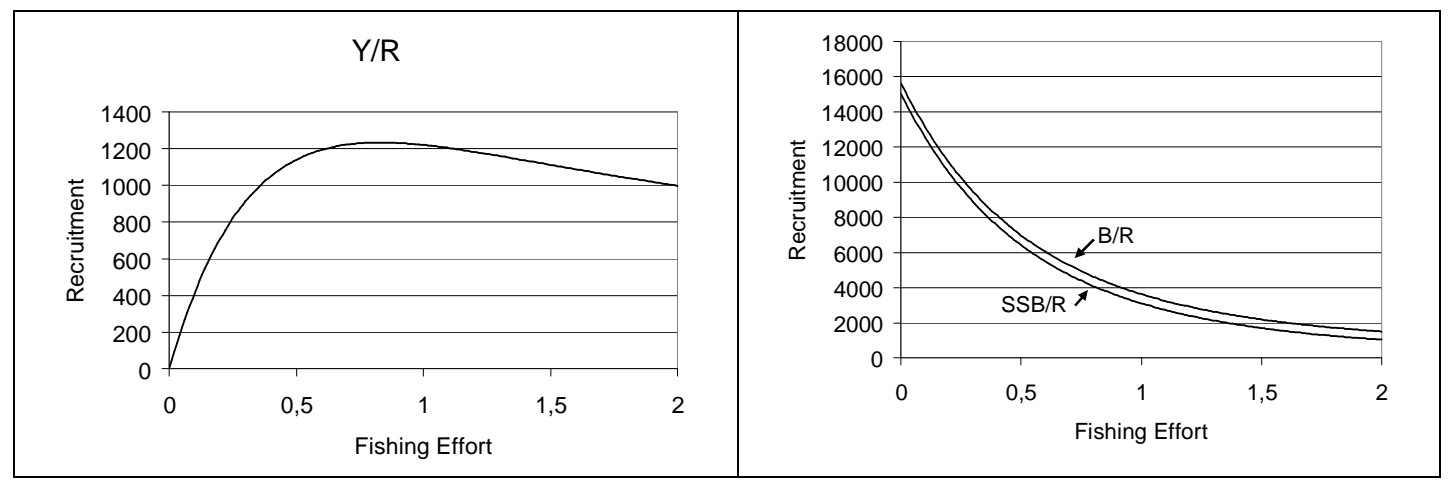

Fig. 3. Yield-per-recruit (Y/R), Biomass-per-recruit (B/R) and Spawning stock biomass-per-recruit (SSB/R) curves, for mutton snapper, Lutjanus analis off Pernambuco State, North-eastern Brazil, continental shelf (see text for details). 
Table 6. Results of the yield-per-recruit analysis for the yellowtail snapper, Lutjanus chrysurus, caught off Pernambuco State, North-eastern Brazil, continental shelf.

\begin{tabular}{|c|c|c|c|}
\hline Slope at origin & & & 2287.8749 \\
\hline Virgin biomass (g) & & & 385210002 \\
\hline Factor & $\mathrm{Y} / \mathrm{R}$ & $\mathrm{B} / \mathrm{R}$ & $\mathrm{SSB} / \mathrm{R}$ \\
\hline 0 & 0 & 5314.849 & 5158.63 \\
\hline 0.37 & 346.302 & 1926.158 & 1771.526 \\
\hline 0.57 & 362.501 & 1282.619 & 1128.779 \\
\hline 1.01 & 337.183 & 677.036 & 524.976 \\
\hline 2 & 287.174 & 393.987 & 245.695 \\
\hline
\end{tabular}

\section{Simulation Analysis}

The simulation, or transition, analysis within the two scenarios of high (increase by $25 \%$ ) and low (decrease by 25\%) fishing effort showed that both stocks are sensitive to changes in the current exploitation pattern. Increasing fishing effort for $L$. analis by $25 \%$ shows that the performance of the indicators of stock status (SSB/R and B/R) would decrease (Fig. 5, left panel), with only short-term (1 yr) gains in yield per recruit (Y/R). Conversely, a decrease by $16 \%$ (close to the policy scenario of $25 \%$ reduction, not shown) of the effort applied would allow an improvement in the performance of the indicators $\mathrm{SSB} / \mathrm{R}$ and $\mathrm{B} / \mathrm{R}$, while ensuring sustained yields (Y/R) in the medium and long term (Fig. 5, right panel): $\mathrm{B} / \mathrm{R}$ would increase by $21 \%$ and $\mathrm{SSB} / \mathrm{R}$ by $91.4 \%$ in the long-term, although $\mathrm{Y} / \mathrm{R}$ would increase only by $0.9 \%$ with respect to present levels. These results show that a $16 \%$ reduction in fishing effort would not jeopardize fisheries' yield of L. analis while allowing for stock recovery over a 20-yr horizon.

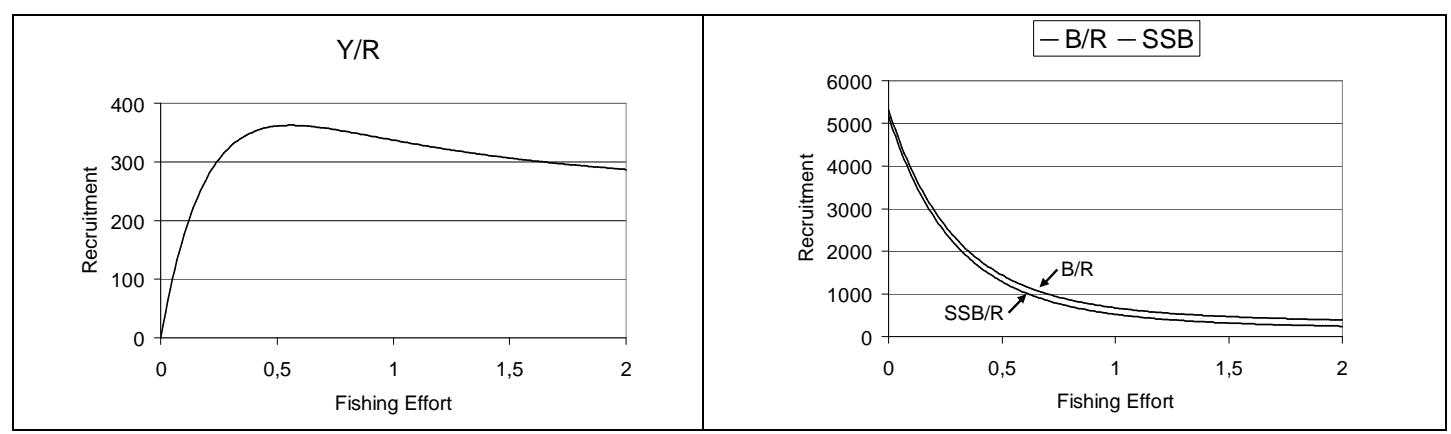

Fig. 4. Yield-per-recruit (Y/R), Biomass-per-recruit (B/R) and Spawning stock biomass-per-recruit (SSB/R) curves, for yellowtail snapper, Lutjanus chrysurus off Pernambuco State, North-eastern Brazil, continental shelf (see text for details).
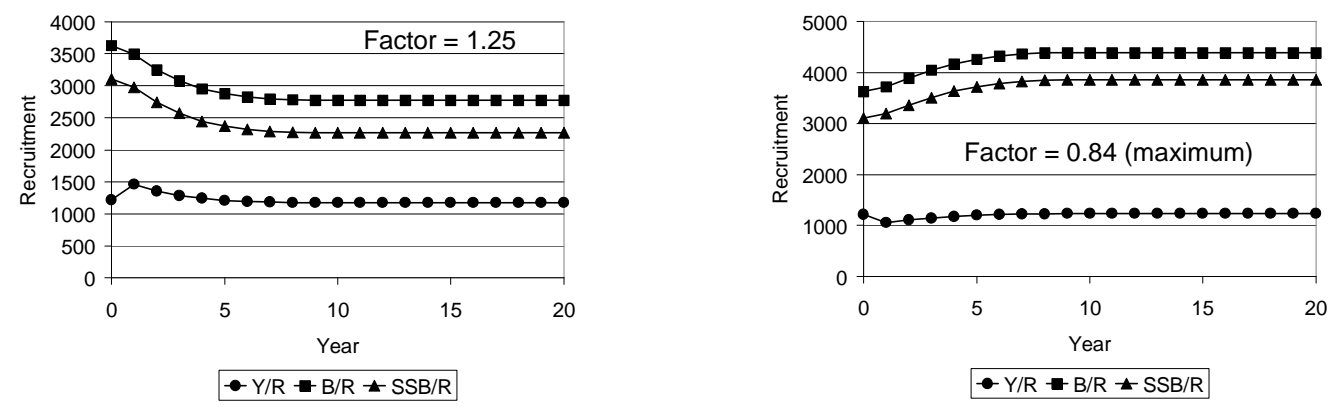

Fig. 5. Results of the simulation analysis under conditions of deterministic recruitment, using a Beverton and Holt's stockrecruitment model, and changes in the factor of effort $(f)$, for mutton snapper, Lutjanus analis, off Pernambuco State, Northeastern Brazil, continental shelf (see text for details). Y/R - Yield-per-recruit; B/R - Biomass-per-recruit; and SSB/R Spawning stock biomass-per-recruit. 
For $L$. analis, the simulation analysis under stochastic conditions, with a simulated Beverton and Holt SSB/R model, showed that variability in recruitment would introduce uncertainty about the exact values of the indicators (SSB/R, B/R and Y/R) analysed over the 20 -yr period, although the trends are the same as for the deterministic scenarios. A $25 \%$ increase in effort would likely reduce the long-term values of $\mathrm{SSB} / \mathrm{R}, \mathrm{B} / \mathrm{R}$ and $\mathrm{Y} / \mathrm{R}$ (Fig. 6), while a reduction of effort to $84 \%$ of the present level would ensure that $\mathrm{SSB} / \mathrm{R}$ and $\mathrm{B} / \mathrm{R}$ would be higher (with $95 \%$ probability) than the present level, while $\mathrm{Y} / \mathrm{R}$ will be higher with a probability of 70\% (Fig. 7).
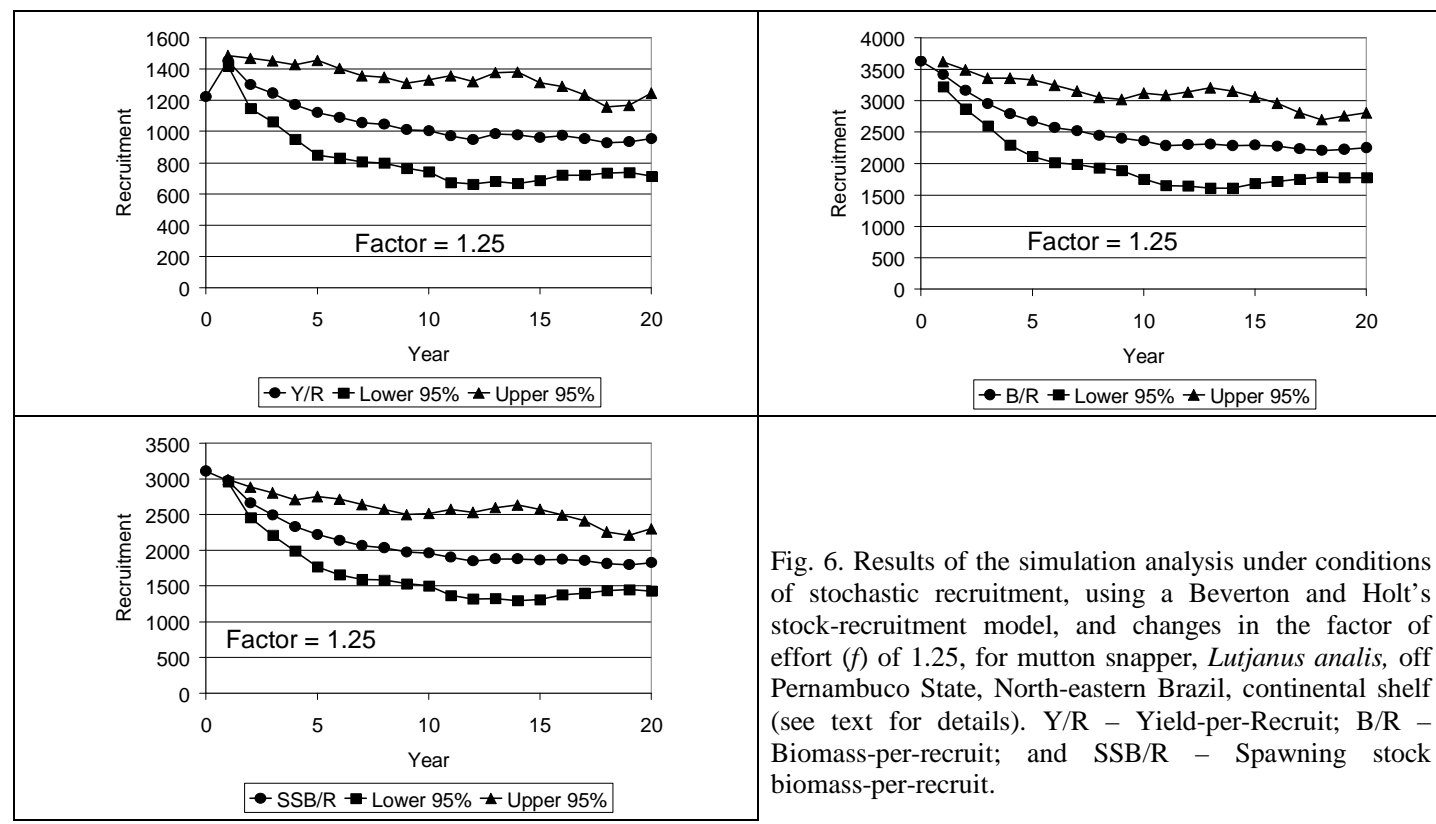

Fig. 6. Results of the simulation analysis under conditions of stochastic recruitment, using a Beverton and Holt's stock-recruitment model, and changes in the factor of effort $(f)$ of 1.25 , for mutton snapper, Lutjanus analis, off Pernambuco State, North-eastern Brazil, continental shelf (see text for details). Y/R - Yield-per-Recruit; B/R Biomass-per-recruit; and SSB/R - Spawning stock biomass-per-recruit.
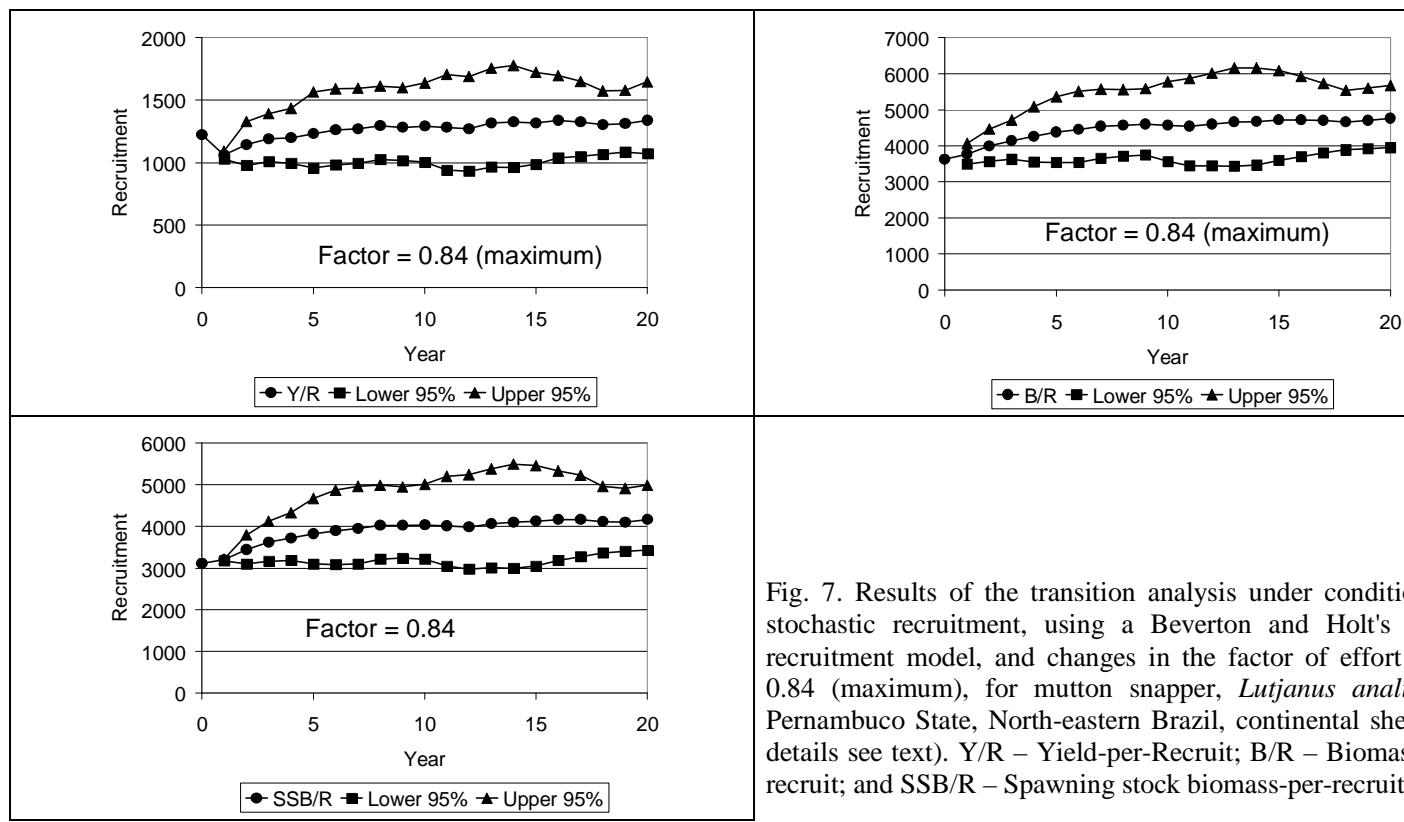

Fig. 7. Results of the transition analysis under conditions of stochastic recruitment, using a Beverton and Holt's stockrecruitment model, and changes in the factor of effort $(f)$ of 0.84 (maximum), for mutton snapper, Lutjanus analis, off Pernambuco State, North-eastern Brazil, continental shelf (for details see text). Y/R - Yield-per-Recruit; B/R - Biomass-perrecruit; and SSB/R - Spawning stock biomass-per-recruit. 
Increasing fishing effort for L. chrysurus by $25 \%$ shows that the performance of the indicators of stock status (SSB/R and B/R) would decrease (Fig. $8 \mathrm{a})$, with only short-term (1 yr) gains in yield per recruit (Y/R), in the deterministic analysis. Conversely, a decrease by $25 \%$ of the effort applied would allow an improvement in the performance of the indicators $\mathrm{SSB} / \mathrm{R}$ and $\mathrm{B} / \mathrm{R}$, while ensuring sustained yields $(Y / R)$ in the medium and long term (Fig. 8b). A fishing effort policy aiming at maximizing the yield of $L$. chrysurus fisheries over the long-term would imply a reduction of effort to $57 \%$ of the present level, producing a strong increase in SSB/R and $\mathrm{B} / \mathrm{R}$, but not producing substantially higher $\mathrm{Y} / \mathrm{R}$ over the long-term (Fig. 8c).

For $L$. chrysurus, the simulation analysis under stochastic conditions, with a simulated Beverton and Holt SSB/R model, shows that variability in recruitment would introduce uncertainty into the indicators ( $\mathrm{SSB} / \mathrm{R}, \mathrm{B} / \mathrm{R}$ and $\mathrm{Y} / \mathrm{R})$ analysed over the 20 -yr period, although the trends are the same as for the deterministic scenarios (Figs 9, 10, 11). A 25\% increase in effort would likely reduce the long-term values of $\mathrm{SSB} / \mathrm{R}, \mathrm{B} / \mathrm{R}$ and $\mathrm{Y} / \mathrm{R}$ with great probability (Fig. 9), while a reduction of effort to $75 \%$ of the present level would ensure that SSB/R and B/R were higher (with $95 \%$ probability) than the present level, while Y/R would be higher with a probability of $60 \%$ (Fig. 10). The fishing effort policy aiming at maximizing the yield of $L$. chrysurus fisheries over the long-term (reduction of effort to $57 \%$ ) would produce a strong increase in $\mathrm{SSB} / \mathrm{R}$ and $\mathrm{B} / \mathrm{R}$, but not a substantially higher Y/R over the long-term (Fig. 11).

\section{Sensitivity Analysis}

For L. analis, the sensitivity analysis of the 3 parameters of von Bertalanffy's growth equation $\left(L_{\infty}, k\right.$ and $t_{0}$ ), the two parameters of the length-weight relationship ( $a$ and $b$ ), the terminal fishing mortality $\left(F_{\text {term }}\right)$ and the natural mortality $(M)$ showed that the most sensitive parameter was the parameter $b$ of the length-weight relationship. This parameter represented a variation in the result of the $Y / R$ analysis of up to $242 \%$, when a factor of 0.1 was applied. The variation in the $Y / R$ analysis due to a change in this parameter, even by a factor of 0.01 , was always higher than $5 \%$, denoting its sensitivity. A factor of 0.1 change in the parameter $a$ of the length-weight relationship induced a variation of up to $10 \%$ in the $Y / R$. Changes in the von Bertalanffy growth parameters by a factor of 0.1 produced changes in $Y / R$ of from $3 \%$ to $33.1 \%$ for $L_{\infty}$, from $1.9 \%$ to $19.2 \%$ for $K$, and from $0.4 \%$ to $3.9 \%$ for $t_{0}$. Terminal fishing mortality $\left(F_{\text {term }}\right)$ was the parameter showing the lowest variation $(0.1 \%-0.7 \%)$ in $\mathrm{Y} / \mathrm{R}$, while changes in $M$ by a factor of 0.1 implied a variation of $Y / R$ lower than $4 \%$.
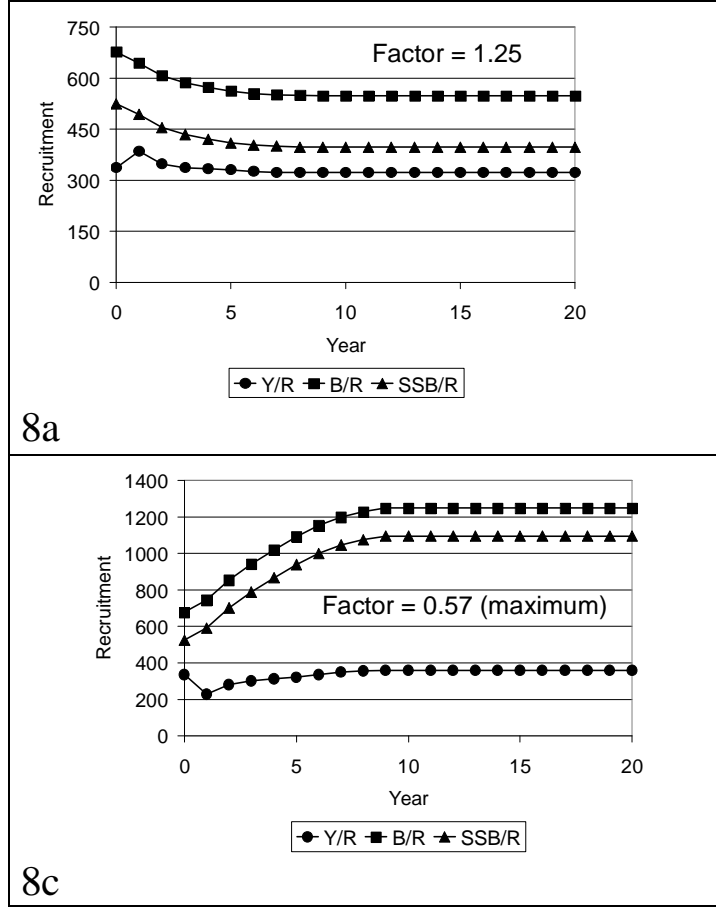

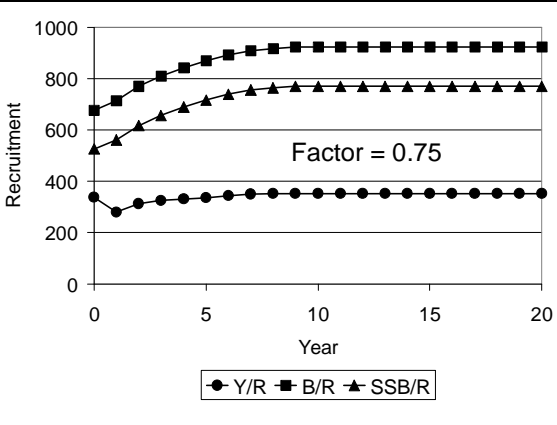

$8 b$

Fig. 8. Results of the simulation analysis under conditions of deterministic recruitment, using a Beverton and Holt's stockrecruitment model, and changes in the factor of effort $(f)$, for yellowtail snapper, Lutjanus chrysurus, off Pernambuco State, North-eastern Brazil, continental shelf (see text for details). Y/R - Yield-per-recruit; B/R - Biomass-per-recruit; and SSB/R - Spawning stock biomass-per-recruit. 

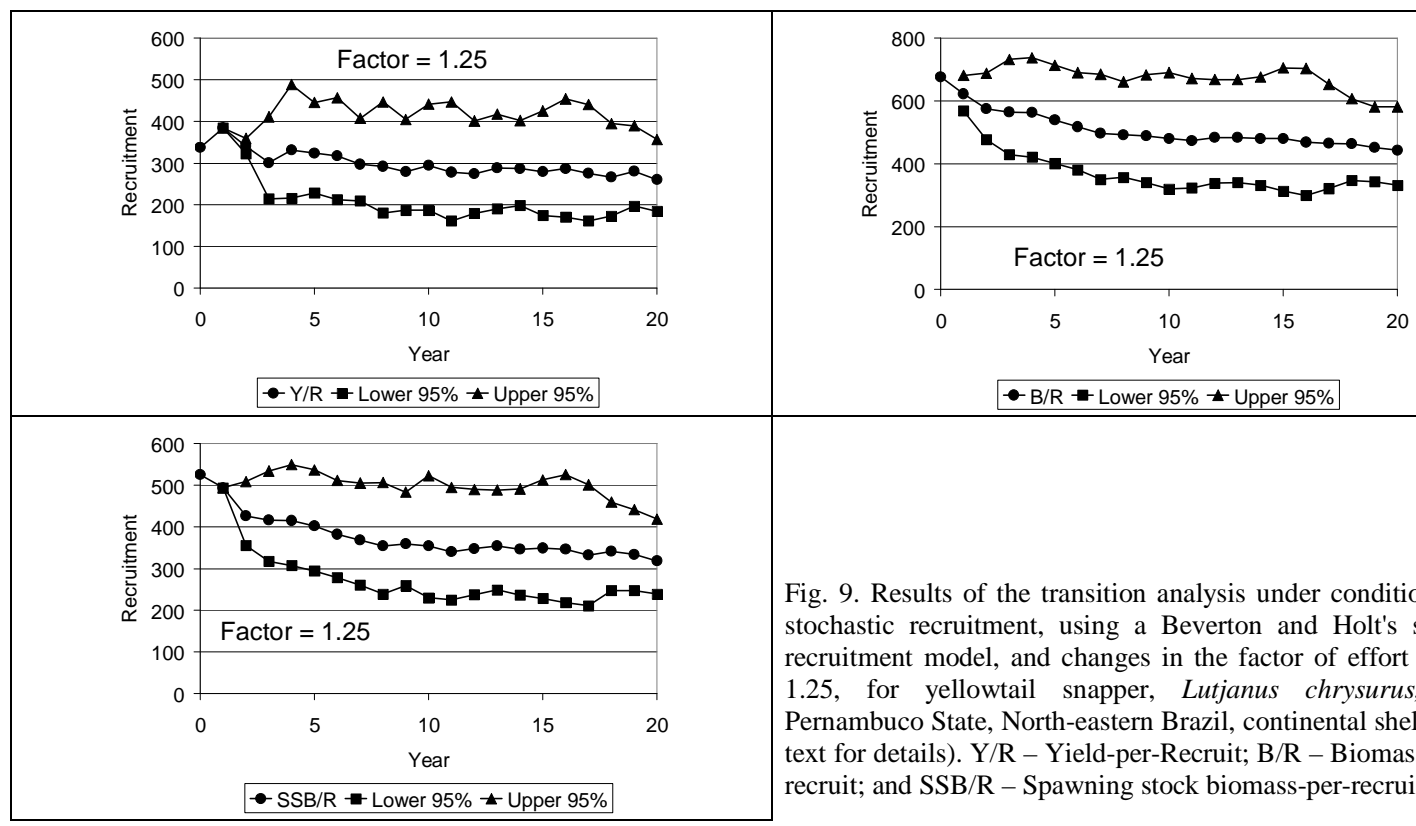

Fig. 9. Results of the transition analysis under conditions of stochastic recruitment, using a Beverton and Holt's stockrecruitment model, and changes in the factor of effort $(f)$ of 1.25 , for yellowtail snapper, Lutjanus chrysurus, off Pernambuco State, North-eastern Brazil, continental shelf (see text for details). Y/R - Yield-per-Recruit; B/R - Biomass-perrecruit; and SSB/R - Spawning stock biomass-per-recruit.
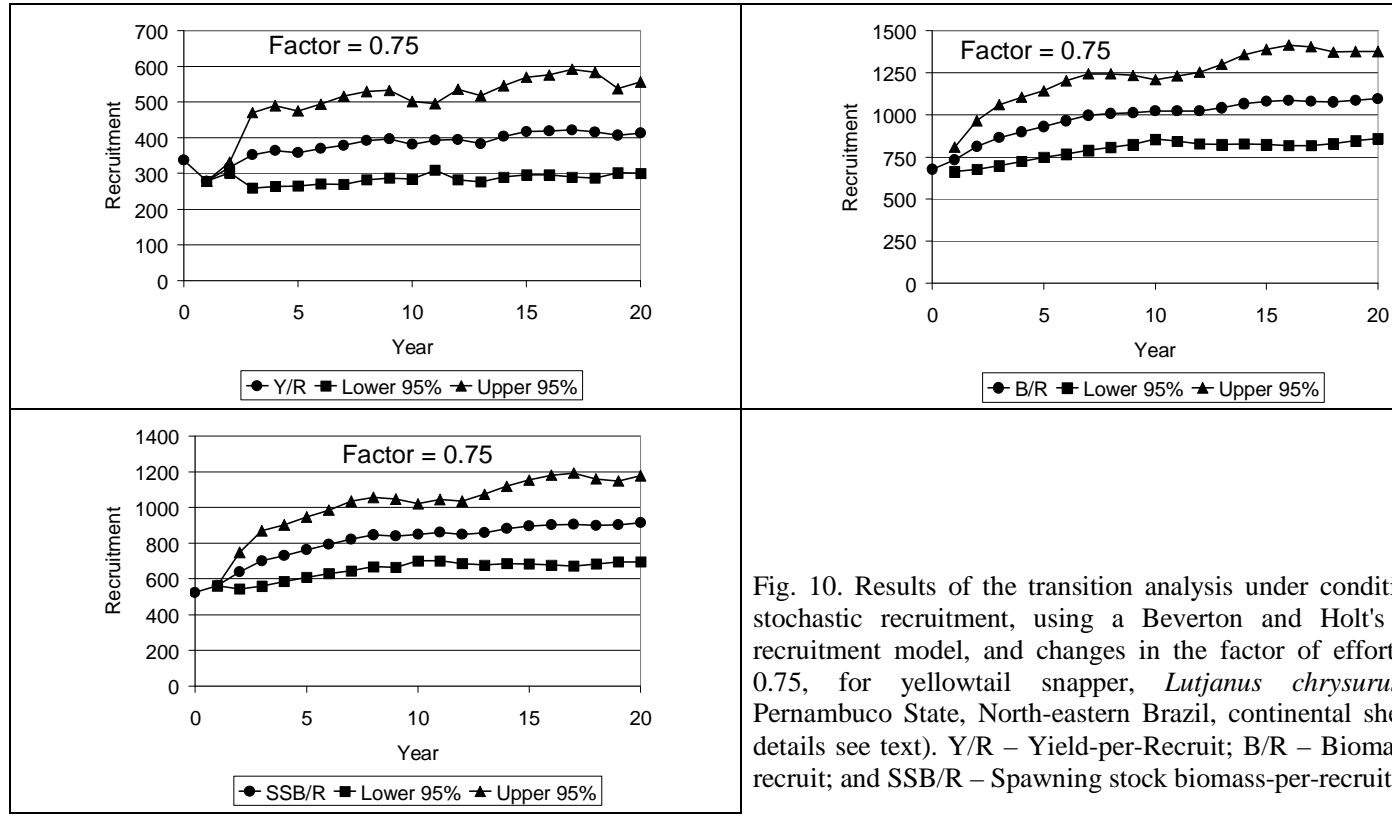

Fig. 10. Results of the transition analysis under conditions of stochastic recruitment, using a Beverton and Holt's stockrecruitment model, and changes in the factor of effort $(f)$ of 0.75, for yellowtail snapper, Lutjanus chrysurus, off Pernambuco State, North-eastern Brazil, continental shelf (for details see text). Y/R - Yield-per-Recruit; B/R - Biomass-perrecruit; and SSB/R - Spawning stock biomass-per-recruit 


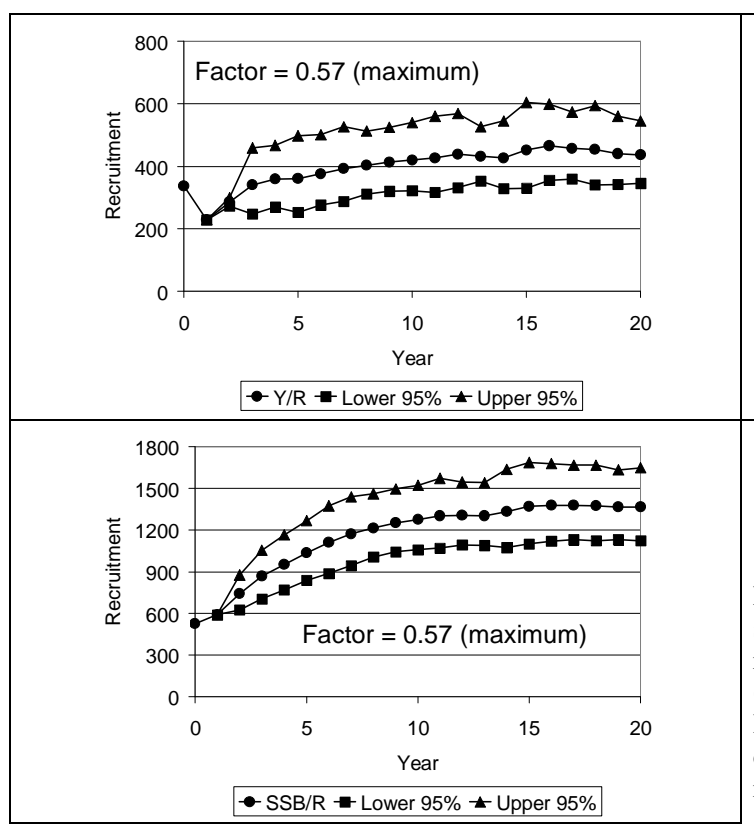

In the case of $L$. chrysurus, the sensitivity analysis showed that the most sensitive parameter was again $b$ of the length-weight relationship, with variation in the $Y / R$ between $68 \%$ and $178 \%$, for a factor of 0.1. Variation in the yield-per-recruit analysis by a change in this parameter, even by a factor of 0.01 , was always higher than $5 \%$, denoting its sensitivity. A factor of 0.1 change in the parameter $a$ of the lengthweight relationship induced a variation of up to $10 \%$ in $Y / R$. Changes in the von Bertalanffy growth parameters by a factor of 0.1 produced changes in $Y / R$ of from $2.8 \%$ to $33 \%$ for $L_{\infty}$, from $1.8 \%$ to $18.9 \%$ for $K$, and from $0.3 \%$ to $3 \%$ for $t_{0}$. Terminal fishing mortality $\left(F_{\text {term }}\right)$ was the parameter showing the lowest variation $(0.01 \%-0.09 \%)$ in $Y / R$, while changes in $M$ by a factor of 0.1 implied a variation of $Y / R$ lower than $4 \%$.

\section{Discussion}

Although concerned that further age and growth studies should be conducted, it seems that, from the results obtained, the method of sizefrequency distribution fitted the analyzed stock sample well. The results obtained by Allen (1985), either for yellowtail snapper or for mutton snapper, are in accordance with the present results concerning length class distribution. Also Froese and Pauly (2003) report, from the work of various authors on both species derived from the Southeastern zone of Cuba, similar values for the von Bertalanffy's growth

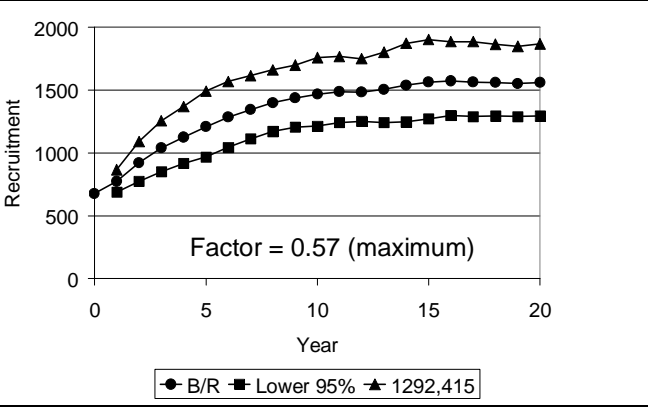

Fig. 11. Results of the transition analysis under conditions of stochastic recruitment, using a Beverton and Holt's stockrecruitment model, and changes in the factor of effort $(f)$ of 0.57 (maximum), for yellowtail snapper, Lutjanus chrysurus, off Pernambuco State, North-eastern Brazil, continental shelf (for details see text). Y/R - Yield-per-Recruit; B/R - Biomass-perrecruit; and SSB/R - Spawning stock biomass-per-recruit.

parameters to those found in the present study: for yellowtail snapper an amplitude on the estimation of $L \infty$ from $40 \mathrm{~cm}$ to $69.3 \mathrm{~cm}$ (fork length used), for $K$ from 0.1 to 0.332 , and for $t_{0}$ from -1.79 to -0.27 ; whereas for mutton snapper an amplitude of $L \infty$ from $78 \mathrm{~cm}$ to $118 \mathrm{~cm}$ (fork length used); $K$ from 0.1 to 0.246; and $t_{0}$ from -1.42 to -0.58 . Close values for the von Bertalanffy's growth parameters of yellowtail snapper for the same region were calculated by Calado Neto et al. (1997) who found an $L \infty$ of $65 \mathrm{~cm}$ (fork length used), a $K$ of 0.2 , and a $t_{0}$ of -0.75 . More recently, Diedhiou et al (2004) studying the yellowtail snapper off the northeastern coast of Brazil found an $L_{\infty}$ $=62.00 ; K=0.05$ and $t_{0}=8.1$. These parameters were obtained from otholit readings, and the authors commented that great size variability by age class was observed, which seriously affects age estimation because the small value of $K$ probably indicates a lack of young specimens in the sample analysed. Leite Jr. et al. (2005) found, through back calculation for this same species, an $L_{\infty}=56.7 ; K=0.13$ and $t_{0}=-0.77$. Alegria and Menezes (1970) studying Lutjanus synagris on the coast of the northeastern region of Brazil, found the following parameters: $L \infty=50.5 \mathrm{~cm}, K=0.23$ and $t 0=$ 0.19 , by the Ford-Walford Method; whilst Lima (2004) and Leite Jr. et al. (2005) found the same parameters for this species through back-calculation: $L \infty=31.17 \mathrm{~cm}, K=0.17$ and $t 0=-0.37$ and $L_{\infty}=31.2$ $\mathrm{cm}, K=0.17$ and $t 0=-0.37$, respectively. Rezende and Ferreira (2003) using the same method as Diedhiou et al (2004), and in the same area, for the study of age and growth of the dog snapper, Lutjanus jocu, a 
species closely related to the mutton snapper, found an $L \infty=77.22 \mathrm{~cm}, K=0.110$ and $t 0=-3.73$. Klippel et al. (2005) assessing the status of six lutjanid stocks caught on the eastern Brazilian coast found the following parameters, for yellowtail snapper and mutton snapper respectively: $L \infty=78.5 \mathrm{~cm}$ and $K=$ 0.156 ; and $L \infty=99.8 \mathrm{~cm}$ and $K=0.133$. From the previous analysis and if we compare other estimations of von Bertalanffy growth parameters, it may be observed that the asymptotic lengths $(L \infty)$ were very similar to those reported by other Brazilian studies for both species. On the other hand, the slightly higher value of $K$, for both species, found in the present study seems to be related to the presence of younger individuals in the sample, because it is known that younger fish present a higher growth rate.

As stressed by Lleonart and Salat (1997), the stationary condition applied to study stocks for the use of VIT software is clearly a very restrictive hypothesis because, in general, the population is not in equilibrium, as neither recruitment nor mortality is constant over time. Knowing the errors associated with accepting these hypotheses does not eliminate them, but does contribute to a well-founded interpretation of the results and produces an objective assessment of the population under study. Our analysis shows that combining a short data series with biological parameters from literature sources we can reconstruct an acceptable virtual population of two species of snapper, even if our initial estimates of $F$ and $M$ are not highly accurate. There is too little information on the rates of fishing $(F)$ and natural $(M)$ mortalities for snappers, in the literature consulted. For yellowtail snapper the rate of $M$ for this species was estimated as $0.112 ; F$ was calculated to be 0.358 ; and the exploitation ratio, given by the relation between fishing and total mortalities (F/Z) was, thus, 0.76 . For mutton snapper $M$ was estimated to be $0.152 ; F$ was calculated to be 0.277 ; and the exploitation ratio was 0.53 . It is well known that $M$ is quite hard to estimate, and many factors - biological and/or ecological - may be involved in the natural mortality of any species of fish. Otherwise, $F$ is directly dependent on the fishing effort $(f)$ applied and its estimation, although straightforward, deserves attention but is highly specific to a particular fishery. Sensitivity analysis shows that the $Y / R$ indicator is very sensitive to misspecification of the $b$ parameter of the allometric curve, showing that a greater sampling endeavour needs to be made for the correct estimation of this parameter.

Small-scale coastal fisheries along the Pernambuco state coast (north-eastern Brazil) are highly diversified, including, as they do, different types of fleet, fishing gear and target species. Due to the large geographic area $\left(c a .1500 \mathrm{~nm}^{2}\right)$ and the lack of government control and regulations, the monitoring and management of these coastal fisheries is extremely difficult. Our results show that the main snapper stocks fished by the hand-line fleet off Pernambuco are slightly overexploited. This fishery would benefit from a reduction of effort, which would result in sustained yields over the long term and better stock health, as measured by the indicators SSB/R (spawning stock biomass-per-recruit) and $\mathrm{B} / \mathrm{R}$ (biomass-per-recruit). Although the VPA analysis shows that $L$. analis would require a $16 \%$ decrease in effort and $L$. chrysurus a decrease of $43 \%$, it is impractical to manage the two species separately. An increase of $25 \%$ in fishing effort would in all probability bring about a considerable decrease in $\mathrm{SSB} / \mathrm{R}$ and $\mathrm{B} / \mathrm{R}$, with lower yields in the long run. Conversely, our proposal to reduce current effort levels by $25 \%$ is a compromise between the two values of effort reduction mentioned and would bring about a substantial increase in SSB/R and B/R levels, with a probability of $95 \%$, while ensuring higher catches than at present with a probability of at least $60 \%$. From the study conducted by Klippel et al. (2005) on six lutjanid stocks caught on the eastern Brazilian coast, through cohort analysis and the Thompson and Bell model of length composition, it was found that these stocks are overexploited, and concerning the two snappers species studied here, they reached similar conclusions to those presented in this study, i.e., that the stock of yellowtail snapper ( $L$. chrysurus) is seriously overexploited; whilst mutton snapper (L. analis) exhibit moderate overexploitation.

It is a matter of concern that scientific information is insufficient and that lack of Brazilian government control makes it unrealistic to propose management measures based on size and effort restrictions, and as the goal is to protect stocks from overfishing, the Brazilian government should consider invoking the precautionary approach at any time to effectively protect the fish habitat, and consequently fishery resources. We agree with Frédou et al. (2006) when they say that to date in fisheries, there have been no studies of fishing activity or its impact that can assimilate the development of a management plan to underpin sustainable exploitation, but as mentioned by Rosenberg (2002), the politics of fishery management may be changing, even if slowly, and even if we have new scientific perspectives, we are still struggling to implement precautionary management nationally and internationally.

The results presented here on the trends of catches for these two species, the population status and the yield-per-recruit $(Y / R)$ analysis, which demonstrate the need for a reduction in the current level of fishing effort $(f)$, probably denote that the yellowtail snapper stock off the Pernambuco continental shelf is more heavily fished than the mutton snapper one. Otherwise, the relatively small variations presented by 
the level of recruits in changing effort factor conditions, either for increasing or decreasing factors, must indicate a close stock-recruitment relationship for both species. On the above cited mortality rates and exploitation ratio, the decreasing trend in catches must be the stocks' response to such a high fishing effort level, which can be clearly evidenced by the estimated exploitation ratio. The diminishing return on effort means that destruction of the population is virtually impossible; the fishery can sustain a great amount of effort, but the resulting yield will be very low indeed. However, the small sample size may be insufficient to indicate the functional form of the stock-recruitment relationship.

Olavo et al. (2005) commented that bathymetric distribution of fishing effort of the line fisheries and the dynamics of the hook and line fishing fleets of Bahia State, operating off the central-eastern coast of Brazil, indicate that the outer continental shelf $(30-80 \mathrm{~m})$ and continental slope concentrate $73.2 \%$ of monitored trips and $76 \%$ of yearly effort due to the relatively higher abundance of reef species associated with such environments, mainly targeting snapper species such as the yellowtail snapper, mutton snapper and dog snapper, as well as pelagic species, due to the high yields attained, seemingly related to reproductive aggregation behavior. Martins et al. (2005) also commented that the hook and line motorized fleet based on the Espírito Santo State, located on the same central-eastern coast of Brazil, whose target species are those of the Lutjanus genus that inhabits the continental slope, and Costa et al. (2005) found that snappers (Lutjanidae) were the most abundant reef species group in the landings sampled (31.6\%), and that the yellowtail snapper was, among this group, the most abundant species in the sample landings. Costa et al. (2005) also found that the species of the Lutjanus genus inhabit a variety of depths on the continental slope. The yellowtail snapper is more abundant between 20 and $30 \mathrm{~m}$, its abundance decreasing at greater depth, though it can still be found at $150 \mathrm{~m}$; the mutton snapper (L. analis) between $60 \mathrm{~m}$ and $70 \mathrm{~m}$; the dog snapper ( $L$. jocu) is more abundant between 40 $\mathrm{m}$ and $50 \mathrm{~m}$, and the vermillion snapper (L. vivanus) from $160 \mathrm{~m}$ to $170 \mathrm{~m}$.

The preceding analysis seems to indicate that the yellowtail snapper, one of the smaller lutjanid species, is more frequent in shallower regions off Pernambuco continental shelf, thus being more vulnerable to the fishing effort applied, due to the accessibility of hand-liners to inshore fishing grounds, and the fishing gear utilised. The mutton snapper, on the other hand, a larger species, may inhabit deeper regions of the platform and the continental slope, whereas the young of this species may be more frequently found in shallower regions. Such stratified distribution has also been discussed by Frédou and
Ferreira (2005) for whom the catch of different Lutjanid species by the artisanal fleet must be related to the operation of the fleet, which varies from shallow to deep waters depending, amongst others factors, on environmental conditions, motorised or wind-driven boats, shelf width, trade winds, etc. Szedlmayer and Conti (1999) mentioned that age-0 red snapper used an inner shelf habitat for their first settlement, and a similar pattern of relationship between fish age and habitat depth was suggested by Bradley and Bryan (1975 apud Szedlmayer and Conti, 1999) for whom young red snapper, during summer months, sought deeper water as they grew older.

The application of steady-state VPA to two snapper stocks ( $L$. analis and L. chrysurus) exploited by artisanal fleets along the Pernambuco coast showed that even a short-data series ( 1 year of sampling) can produce a useful diagnosis of fishery resources. By incorporating the results of VPA into a simulation framework, we can develop a comparison of the likely result of different policy options (effort regulation) based on 3 simple indicators (Spawning stock biomass-per-recruit, Biomass-per-recruit and Yield-per-recruit). Even while recognizing the difficulty of testing the assumptions introduced into our model (steady-state, Beverton and Holt recruitment model) and using standard fisheries analysis techniques, we show that guidance can be offered within a context of limited fishery data. Providing advice for the assessment of coastal fisheries is an urgent issue, given the high dependence of local communities on coastal living resources and the increasing fishing effort applied by a growing population.

\section{ACKNOWLEDGEMENTS}

We would like to acknowledge the support of the Institut de Ciències del Mar - ICM/CSIC (Spain) and the Superintendência do Desenvolvimento do Nordeste - SUDENE (Brazil), as well as the fishermen of the Colônias dos Pescadores Z-25 (Jaboatão dos Guararapes, Pernambuco, Brazil) and Grupo de Apoio à Pesca - GAP for data collection.

\section{REFERENCES}

ALEGRIA, J. R. C., MENEZES, M. F. Edad y crecimento del ariacó, Lutjanus synagris (Linnaeus), en el nordeste del Brasil. Arq. Ciênc. Mar, Universidade Federal do Ceará, , v. 10, n. 1, p. 65- 68, 1970.

ALLEN, G. R. 1985. Snappers of the world. An annotated and illustrated catalogue of lutjanid species known to date. FAO Species Catalogue. FAO Fish Synop., v. 6, n. 125, 208 p., 1985. 
CALADO NETO, A. V.; SILVA, A. L. N.; MATTOS, S. M. G. Aspecto da dinâmica populacional da guaiúba, Ocyurus chrysurus (Bloch, 1791) do litoral do Estado de Pernambuco. Bolm técn. Cient. CEPENE, v. 5, n. 1, p. 73-87, 1997.

CARVALHO FILHO, A. Peixes: costa brasileira. São Paulo, Editora Metro, 1999. $320 \mathrm{p}$.

COSTA, P. A. S.; OLAVO, G.; MARTINS, A. S. Áreas de pesca e rendimentos da frota de linheiros na região central da costa brasileira entre Salvador-BA e o Cabo de São Tomé-RJ. In: COSTA, P.A.S.; MARTINS, A. S.; OLAVO, G. (Ed.). Pesca e potenciais de exploração de recursos vivos na região central da Zona Econômica Exclusiva brasileira. Rio de Janeiro: Museu Nacional, 2005. p. 57-70. (Série Livros n.13).

DIEDHIOU M.; FERREIRA B. P.; REZENDE S. M. Idade e crescimento da Guaiúba, Lutjanus chrysurus (Bloch 1791), na Costa Nordeste do Brasil. Arq. Ciênc. Mar, Universidade Federal do Ceará, v. 37, p. 39-52, 2004.

FAO. Code of conduct for responsible fisheries. Rome, 1995. $41 \mathrm{p}$.

FREDOU, T.; FERREIRA, B. P. Bathymetric trends of northeastern Brazilian snappers (Pisces, Lutjanidae): implications for the reef fishery dynamic. Braz. Arch. Biol. Technol., v. 48, n. 5, p. 787-800, 2005.

FRÉDOU, T.; FERREIRA, B. P.; LETOURNEUR, Y. A univariate and multivariate study of reef fisheries off northeastern Brazil. ICES J. mar. Sci., v. 63, p. 883896,2006

FROESE, R.; PAULY, D. (Ed.). FishBase. World Wide Web electronic publication, 2003. < www.fishbase.org.>

GAYANILO Jr.; F. C.; SPARRE, P.; PAULY, D. FAO and ICLARM Stock Assessment Tool (FISAT II). FAO Computerised Information Series, 2002. Online User Guide.

GULLAND, J. A. Manual of methods for fish stock assessment. Part 1. Fish population analysis. Roma: FAO Manuals in Fisheries Science, n. 4, 1969. 154 p.

IBAMA. Boletim Estatístico da Pesca Marítima e Estuarina do Estado de Pernambuco.Tamandaré, PE: CEPENE, 2003.

IBAMA. Boletim Estatístico da Pesca Marítima e Estuarina do Estado de Pernambuco. Tamandaré: CEPENE, 2007.

KLIPPEL, S.; OLAVO, G.; COSTA, P. A. S.; MARTINS, A. S.; PERES, M. B. Avaliação dos estoques de lutjanídeos da costa central do Brasil: análise de coortes e modelo preditivo de Thompson e Bell para comprimentos.In: COSTA, P.A.S.; MARTINS, A. S.; OLAVO, G. (Ed.). Pesca e potenciais de exploração de recursos vivos na região central da Zona Econômica Exclusiva brasileira. Rio de Janeiro: Museu Nacional, 2005. p. 8398 (Série Livros n.13).

LEITE JR., N. O.; MARTINS, A. S.; ARAÚJO, J. N. Idade e crescimento de peixes recifais na região central da Zona Econômica Exclusiva entre Salvador-BA e o Cabo de São Tomé-RJ $\left(13^{\circ} \mathrm{S}\right.$ a $\left.22^{\circ} \mathrm{S}\right)$. In: COSTA, P.A.S.; MARTINS, A. S.; OLAVO, G. (Ed.). Pesca e potenciais de exploração de recursos vivos na região central da Zona Econômica Exclusiva brasileira. Rio de Janeiro: Museu Nacional, 2005. p. 203-216.(Série Livros n.13).
LIMA, W. B. 2004. Idade e crescimento do ariacó, Lutjanus synagris, da costa norte da Bahia. (Monografia) - Programa de Graduação em Oceanografia, Universidade Federal do Espírito Santo, Vitória, 2004.

LLEONART, J.; SALAT, J. 1997. VIT: Software for fishery analysis - User's manual. FAO Computerized Information Series - Fisheries, n. 11, 1997. 110 p.

MARTINS, A. S.; OLAVO, G.; COSTA, P. A. S. A pesca de linha de alto mar realizada por frotas sediadas no Espírito Santo, Brasil. In: COSTA, P.A.S.; MARTINS, A. S.; OLAVO, G. (Ed.). Pesca e potenciais de exploração de recursos vivos na região central da Zona Econômica Exclusiva brasileira. Rio de Janeiro: Museu Nacional, 2005. p.35-55. (Série Livros n.13).

MATTOS, S. M. G. A bioeconomic analysis of the coastal fishery of Pernambuco State, North-eastern Brazil. Ph.D. Thesis, Universitat Politècnica de Catalunya, Barcelona, 2004.

MATTOS, S. M. G.; MAYNOU, F.; FRANQUESA., R. A bio-economic analysis of the hand-line and gillnet coastal fisheries of Pernambuco State, north-eastern Brazil. Scient. Mar., v. 70, n. 2, p. 335-346, 2006.

OLAVO, G.; COSTA, P. A. S.; MARTINS, A. S. Caracterização da pesca de linha e dinâmica das frotas linheiras da Bahia, Brasil. In: COSTA, P.A.S.; MARTINS, A. S.; OLAVO, G. (Ed.). Pesca e potenciais de exploração de recursos vivos na região central da Zona Econômica Exclusiva brasileira. Rio de Janeiro: Museu Nacional, 2005. p. 13-34 (Série Livros n.13)

PERRINGS, C. Sustainability indicators for fisheries in integrated coastal area management. Mar. Freshwater Res., v. 51: 513-522, 2000.

REZENDE S. M.; FERREIRA B. P. Age, growth and mortality of dog snapper Lutjanus jocu (Bloch \& Schneider 1801) in the northeast coast of Brazil. Submitted Braz. J. Oceanogr.

SPARRE, P.; URSIN, E.; VENEMA, S. C. Introduction to tropical fish stock assessment. Part 1. FAO Fish. tech. Pap., n. 306/1, 1989. 404 p. Manual.

SZEDLMAYER, S. T.; CONTI, J. Nursery habitats, growth rates, and seasonality of age-0 red snapper, Lutjanus campechanus, in the northeast Gulf of Mexico. Fish. Bull., v. 97:626-635, 1999.

TEIXEIRA, S. F.; FERREIRA, B. P.; PADOVAN, I. Aspects of fishing and reproduction of the black grouper Mycteroperca bonaci (Poey, 1860) (Serranidae:. Neotrop. Ichthyol., Brasil, v. 2, n. 1, p. 1-44, 2004.

WILLMANN, R.; GARCÍA, S. M. 1986. Modelo bioeconómico para el análisis de pesquerías secuenciales artesanales e industriales de camarón tropical. FAO Doc. técn. Pesca, n. 270, 47 p., 1986.

(Manuscript received 02 October 2007; revised 17 April 2008; accepted 15 June 2009) 